УДК 351

DOI: https://doi.org/10.26642/jen-2020-2(92)-107-113

Л.В. Сергіснко, к.держ.упр.

І.В. Новосьолов, магістрант

Державний університет «Житомирська політехніка»

\title{
Напрями трансформації системи публічного управління в умовах урбанізаційних змін
}

\begin{abstract}
Урбанізаційна проблематика, з огляду на тенденції розширення міст, збільшення агломерацій та перетворення мегаполісів на центри продукування важливих управлінських рішень, формування світового порядку денного, визнана однією із нагальних та актуальних на сьогодні. Адже процеси урбанізачії зачіпають усі сфери життєдіяльності суспільства в цілому та є важливим чинником впливу на безпечне співіснування громадян на окремій території. Наслідки урбанізаційних прочесів, з одного боку, забезпечують ичивілізаційний розвиток та створюють нові можливості у забезпеченні інтересів та потреб людини, а з другого боку, формують нові виклики і завдання як для суспільства, держав, урядів, так і відповідно для системи публічного управління та адміністрування, щуо покликана забезпечити належний рівень якості життя населення, дотримання прав та свобод громадян. 3 метою ідентифікаціі наслідків урбанізаџії та відповідно завдань публічного управління щзодо їх мінімізачії визначено сутність поняття «урбанізація» та встановлено ї̈ наслідки з позицій екологічного, економічного, соиіального та гуманітарного середовищ. Урбанізаційні процеси загострюють екологічні проблеми, пов'язані із забрудненням навколишнього середовища та накопиченням відходів, видобутком корисних копалин, зменшенням природних ресурсів тощо. У той же час актуалізується питання збільшення сочіальної нерівності, збільшення різниці між умовами життя різних груп населення як між краӥнами, так $і$ в межах міст, а також між містами окремої країни. Загострюються також проблеми економічного середовища та гуманітарноі сфери. Задля ефективної ідентифікації проблем та провадження ефективної політики органи влади розширюють можливості долучення громадян до процесу прийняття публічних рішень, адже це дозволяє максимально збільшити спектр стейкхолдерів та відповідно визначити їх інтереси. У цььому дослідженні здійснено структуризацію урбанізаційних викликів із позиціі теорії ісрархічних потреб А.Маслоу, на основі якої встановлено завдання публічного управління та адміністрування та відповідно напрями трансформації системи публічного управління.
\end{abstract}

Ключові слова: урбанізація; публічне управління та адміністрування; державна політика; урбанізаційні процеси.

Актуальність теми. Урбанізаційні процеси, особливо в сучасних умовах глобалізації, торкаються усіх сфер та галузей суспільного життя, змінюють взаємозв'язки між людьми та визначають тенденції розвитку людства. Україна $є$ частиною світових урбанізаційних процесів, що характеризуються стрімкими темпами зростання частки міського населення, кількості і розміру міст. Зміни, обумовлені розвитком урбанізаційних процесів, спричиняють як позитивні, так і негативні наслідки, моніторинг та ідентифікація яких $є$ необхідною умовою прийняття ефективних публічно-управлінських рішень та формування і реалізації публічної політики у забезпеченні інтересів громадян. Зазначене формує перед урядами країн, системами публічного управління та адміністрування завдання щодо забезпечення належного рівня економічного добробуту, екологічної рівноваги, соціального балансу тощо.

Аналіз останніх досліджень та публікації, на які спирається автор. Наукові напрацювання вітчизняних дослідників у сфері урбанізації, що присвячені: вивченню стійкості міських агломерацій та впливу урбанізаційних процесів на регіональний розвиток належать М.Ф. Аверкиній, Т.Б. Заставецькому, Д.М. Котенок та іншим; дослідженню методологічних засад сучасних міських процесів, методології управління сталим розвитком міста, пошуку шляхів забезпечення розвитку міст та агломерацій присвячені праці О.В. Балуєвої, М.А. Міненко, В.І. Бендюга, Б.М. Комариста, А.С. Буряченко та інших. Урбанізаційна проблематика також розглядається 3 позицій впливу на екологічну, соціальну та економічну складові, що підтверджується низкою наукових досліджень як вітчизняних вчених, так і зарубіжних дослідників, серед яких праці А.Аллена (A.Allen), Дж.Бікнелла (J.Bicknell), Д.Догмана (D.Dodman), Д.Саттерсвейта (D.Satterthwaite), Т.Бітлей (T.Beatley), С.Леманна (S.Lehmann), П.Ньюмана (P.Newman), А.Матана (A.Matan), Р.Реджістер (R.Register) та інших, що відображають результати взаємозв'язку урбанізації і сталого розвитку; а також наукові дослідження Роба Кітчина (Rob Kitchin) та Стефана Грема (Stephen Graham), присвячені проблематиці сучасного розвитку міст, використання «великих даних» для потреб міста в реальному часі, теорій мережевого урбанізму.

(C) Л.В. Сергієнко, І.В. Новосьолов, 2020 
Метою статті $€$ обгрунтування напрямів трансформації системи публічного управління та адміністрування в умовах урбанізаційних змін.

Викладення основного матеріалу. Ефективна система публічного управління та адміністрування має бути сконцентрована на дотриманні прав та свобод, забезпеченні потреб та інтересів людини й суспільства. Взаємозв'язок потреб та інтересів із системою публічного управління, а також значення державного управління та місцевого самоврядування в підвищенні якості життя населення вивчено як у наукових, так і в навчально-методичних працях відомих вчених [1-4] у галузі науки публічного управління та адміністрування.

Визначальний характер потреб та інтересів людини у формуванні цілей, завдань публічного управління розкрито у науковій праці [5] та обгрунтовано, що «ефективність публічного управління визначається досягнутим рівнем задоволення потреб та інтересів людини, що є основою публічноуправлінської діяльності». Процес ідентифікації та забезпечення потреб у системі публічного управління змінюється внаслідок впливу різних факторів. Особливо гостро актуалізується ця проблематика в умовах урбанізації, що, в свою чергу, формує нові завдання перед системою публічного управління та адміністрування.

Серед сфер, у яких яскраво прослідковуються зміни внаслідок впливу урбанізаційних процесів, можна виокремити екологічну, соціальну, економічну та гуманітарну, що, в свою чергу, актуалізують відповідну проблематику, вирішення якої потребує публічно-управлінського втручання. Наслідки урбанізації у контексті екологічної, економічної, соціальної та гуманітарної сфер наведено на рисунку 1.

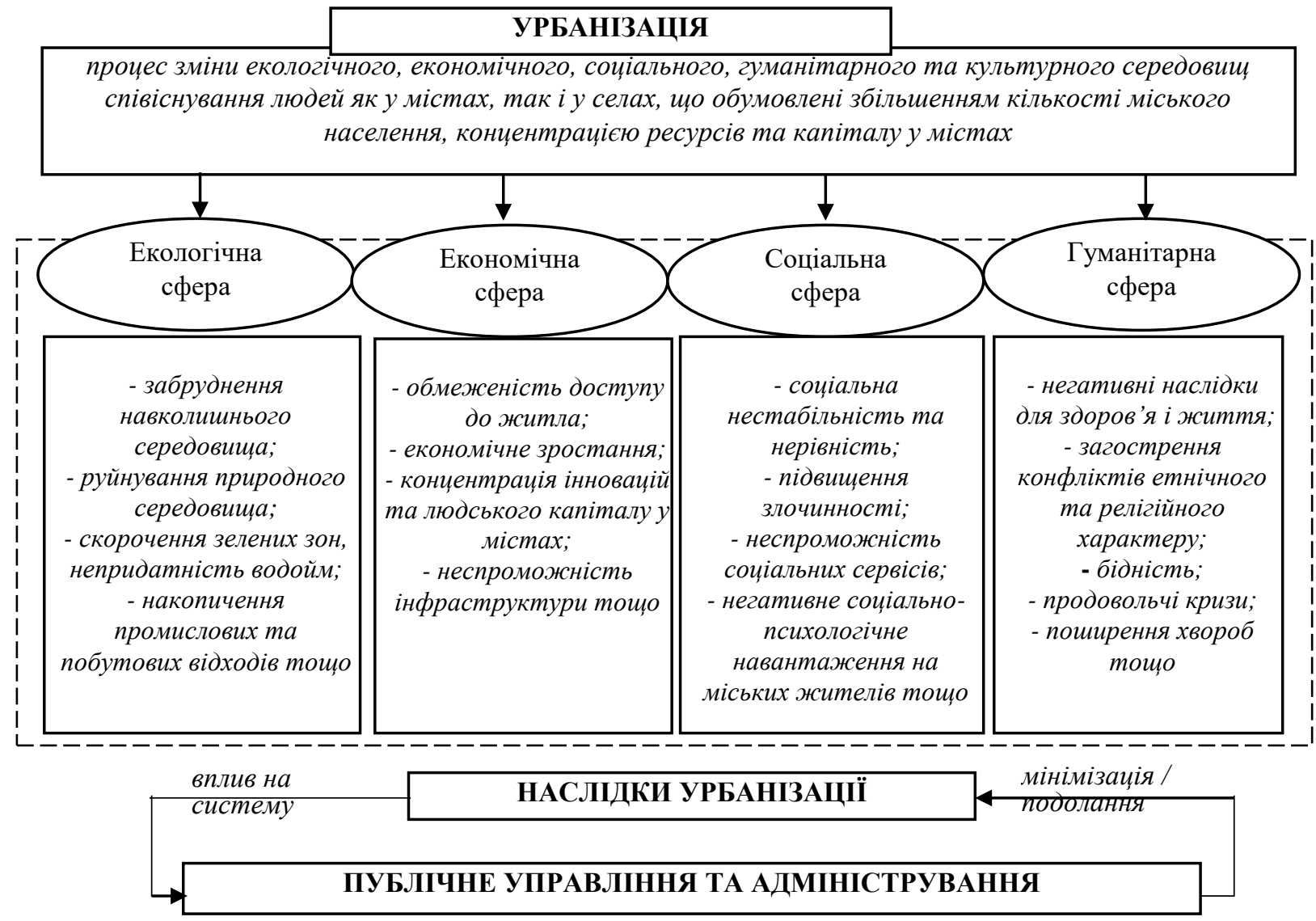

Рис. 1. Наслідки урбанізації у розрізі екологічної, економічної, соичіальної та гуманітарної сфер

Наслідки урбанізації у контексті екологічної, економічної, соціальної та гуманітарної сфер взаємообумовлені. Концентрація промислових комплексів, інновацій, капіталу та ресурсів на певній території обумовлює економічне зростання та є причиною переміщення осіб та збільшення кількості жителів.

Урбанізація як процес збільшення кількості міського населення, концентрації ресурсів та капіталу у містах чинить негативний тиск на інші сфери життєдіяльності суспільства, а саме: підвищення рівня забруднення навколишнього середовища, поширення інфекційних хвороб, в тому числі і внаслідок неспроможності інфраструктури, незадовільного стану комунальної системи міст та накопичення значного обсягу промислових та побутових відходів; руйнування природного середовища міст, 
скорочення зелених зон, непридатність водойм тощо, що, як наслідок, впливає на здоров'я та якість життя населення; соціальна нестабільність та нерівність, у тому числі і внаслідок обмеженого доступу до ресурсів, підвищення рівня безробіття та обмеженого доступу до житла, а також неспроможність соціальної системи забезпечити потреби суспільства, що, в свою чергу, впливає на підвищення соціальної напруги та злочинності; загострення конфліктів етнічного та релігійного характеру внаслідок співіснування груп людей із суперечливими етнічними, релігійними, міжконфесійними інтересами. Окреслений перелік наслідків урбанізації не $\epsilon$ вичерпним, однак зазначена проблематика уже актуалізується у сучасних умовах та потребує розв'язання.

Центральне розвідувальне управління [6] зазначає критерії, за якими можна оцінити ризики урбанізації, а саме: «різнорідність міського населення, до якого належить визначення ступеня нерівномірності доходів, етнічних чи релігійних суперечностей; темпи зростання населення, адже у випадку, якщо вони високі, може створюватися напруга у суспільстві; економічні можливості, зокрема якісна оцінка можливості чи неможливості мешканців влаштувати чи покращити своє життя; наявність необхідних для життя мінімумів, тобто частка міських жителів, що не мають доступу до питної води, стічної системи, системи вивезення твердих відходів тощо; екологічні умови з позицій вивчення частки міських жителів, що страждає від забруднення води чи повітря, антисанітарного довкілля тощо; урядова ефективність, що полягає у відносній оцінці можливостей влади керувати зростанням міст, фінансувати необхідні проєкти, боротися з викликами, пов'язаними з цим зростанням».

Наслідки та ризики урбанізації мають каскадний характер, взаємообумовлені та мають прояв у різних сферах, що потребує комплексного механізму публічного управління у забезпеченні їх мінімізації чи подолання.

Глобальні тенденції збільшення чисельності населення, укрупнення міст, виснаження природних ресурсів, збільшення соціальної нерівності, неможливість забезпечення потреб існуючими інструментами тощо обумовлюють пошук нових моделей управління та зміну філософії мислення. Пануюча на сьогодні концепція сталого розвитку та Цілі сталого розвитку - 2030 передбачають дії, спрямовані на те, щоб покінчити з бідністю, захистити планету й забезпечити мир і процвітання для всіх людей у світі та визначають порядок денний у глобальному масштабі.

Сімнадцять цілей сталого розвитку прямо чи опосередковано спрямовані на уникнення / мінімізацію наслідків урбанізаційних процесів із позицій соціальної, економічної та екологічної рівноваги, однак, 11 ціль безпосередньо стосується забезпечення сталого розвитку міст та спільнот, визначена у Цілях сталого розвитку 2030 [7], як дії щодо подолання урбанізаційних викликів: «більше половини населення світу проживає в міських районах. До 2050 року ця цифра зросте до 6,5 млрд людей, тобто до двох третин усього людства. Сталого розвитку не можна досягти без істотного перетворення того, яким чином ми будуємо міські райони і керуємо ними. Швидке зростання міст у країнах, що розвиваються, одночасно з активізацією міграції з сільських районів до міста, викликало бум у мегаполісах. У 1990 році налічувалося 10 мегаполісів, що мали 10 млн жителів або більше. У 2014 році мегаполісів стало 28, де проживає 453 мільйони. У міських районах нерідко зосереджена крайня бідність, а національним і міським органам влади непросто розмістити зростаюче населення на таких територіях. Досягнення безпеки і сталого розвитку міст означає забезпечення доступним і безпечним житлом, а також модернізацію нетрів. Це також передбачає інвестиції у громадський транспорт, створення зелених громадських територій, а також удосконалення міського планування і управління у такий спосіб, що одночасно забезпечуватиме інклюзивність і загальну рівноправну участь».

Нездатність урядів забезпечити належну інфраструктуру та державні послуги лежить в основі багатьох міських викликів країн, що розвиваються.

3 метою визначення завдань системи публічного управління та адміністрування в умовах урбанізації, використано теорію ієрархічних потреб Абрахама Маслоу (піраміда потреб А.Маслоу) як основу для структуризації урбанізаційних викликів та їх впливу на системи співіснування людей.

Модель структуризації урбанізаційних викликів з позицій використання ієрархії потреб за А.Маслоу та ідентифікації завдань публічного управління в окреслених умовах зображено на рисунку 2. 
Втрата автономії особи - життя за жорстким графіком; обмеження сочіальноі взаємодї; розширення можливостей за умови обмеженого доступу до них; загострення соиіальної нерівності та упередженості тощо

$\int \begin{gathered}\text { соціальной нерівності та упередженості тощо } \\ \text { Незадовільність інфраструктури; неспроможність влади надати якісні } \\ \text { адміністративні послуги та забезпечити потреби особистості та ін. }\end{gathered}$

\begin{tabular}{|c|c|c|c|c|c|c|}
\hline$-\cdot \cdot \cdot \cdot \cdot-\cdot-\cdot$ & визначають напрями &.- & ПУБЛІЧНЕ У & АВЛІННЯ & & j \\
\hline & & & - & & & \\
\hline $\begin{array}{c}\text { Мінімізація } \\
\text { антропогенного } \\
\text { впливу }\end{array}$ & $\begin{array}{c}\text { Модернізація } \\
\text { інфраструктури }\end{array}$ & $\begin{array}{c}\text { Забезпечення } \\
\text { доступним } \\
\text { житлом }\end{array}$ & $\begin{array}{c}\text { Побудова } \\
\text { соиіальної } \\
\text { інфраструктури }\end{array}$ & $\begin{array}{c}\text { Розвиток взаємодї } \\
\text { держава-бізнес- } \\
\text { суспільство }\end{array}$ & $\begin{array}{c}\text { Розвиток } \\
\text { nартисипаціï }\end{array}$ & $\begin{array}{c}\text { Подолання бідності, } \\
\text { економічної та } \\
\text { сочіальної. нерівності }\end{array}$ \\
\hline
\end{tabular}

Рис. 2. Модель структуризаиії урбанізачійних викликів з позичії теорії ієрархічних потреб за А.Маслоу: ідентифікаиія завдань публічного управління 
Використання ієрархії потреб за А.Маслоу дозволило структурувати виклики урбанізації та окреслити завдання публічного управління, що в свою чергу конкретизуються внаслідок урбанізаційних змін. Задоволення потреб ускладнюється урбанізаційними викликами, а саме у контексті:

- фізіологічних потреб (потреби у диханні, воді, їжі, відпочинку) - це урбанізаційні виклики щодо забруднення повітря, води, довкілля, накопичення промислових та побутових відходів, що займають значні території та обумовлюють поширення інфекцій; необхідність пошуку альтернативних шляхів споживання енергії; продовольчі кризи, голод тощо;

- потреб у безпеці (безпеці здоров’я, майна, заощаджень) - це виклики, що полягають у підвищенні захворюваності, внаслідок підвищення швидкості поширення та більшої вірогідності спалахів інфекційних хвороб, підвищенні рівня злочинності, обмеженості доступу до житла тощо;

- соціальних потреб (потреб у дружбі, сім'ї, емоційних аспектах) - це виклики, що полягають у збільшенні соціальної нерівності, загостренні соціальних проблем, таких як: алко- та наркозалежність, психічні розлади, соціальне виключення, підвищенні рівня безробіття, бідності тощо;

- потреб у повазі (досягнення, повага іншими, самоповага та ін.) - виклики, що перешкоджають досягненням людини внаслідок незадовільного стану інфраструктури, неспроможності влади надати якісні адміністративні послуги та забезпечити потреби особистості тощо;

- потреб у самовираженні (тобто потреби розвитку особистості, реалізації своїх цілей та здібностей, моралі, творчості, вирішенні проблем, відсутності упередженості та ін.) - це виклики, що перешкоджають самоствердженню особистості та ії̈ самореалізації, обумовлені втратою автономії особи, адже урбанізовані міста вимагають життя за жорстким графіком, а також виклики, що полягають у обмеженні соціальної взаємодії; розширенні можливостей за умови обмеженого доступу до них, загостренні соціальної нерівності, упередженості тощо.

Отже, серед завдань публічного управління, в умовах впливу урбанізації на екологічну, економічну, соціальну та гуманітарну сфери життєдіяльності та співіснування громадян, доцільно виокремити такі:

- мінімізація антропогенного впливу на довкілля шляхом нормування викидів, перехід на сталі моделі виробництва та споживання, використання альтернативних джерел енергії та ін.;

- модернізація та розвиток інфраструктури в забезпеченні потреб у громадському транспорті, освітніх послугах, послугах із охорони здоров'я та інших;

- забезпечення доступним житлом, що дозволяє вирішити низку негативних наслідків, що обумовлені розширенням нетрів, поширенням інфекції, неконтрольованими соціальними процесами, підвищенням рівня злочинності внаслідок необхідності забезпечення потреб у безпеці;

- побудова соціальної інфраструктури, що передбачає безпечний, доступний, екологічний та якісний громадський простір, сприятливий для розвитку соціальної комунікації та взаємодії, який позитивно впливатиме соціальну згуртованість під час визначення і забезпечення потреб уразливих верств населення;

- розвиток взаємодії держава - бізнес - суспільство з метою об’єднання зусиль та ресурсів у напрямі покращення міського простору, забезпечення потреб та подолання урбанізаційних наслідків;

- розвиток партисипації з метою забезпечення участі громадян в ухваленні важливих публічноуправлінських рішень, залученості до процесу формування та реалізації публічної політики та фокусуванні на реальних потребах жителів громади;

- подолання бідності, економічної та соціальної нерівності задля мінімізації інших каскадних ефектів урбанізаційного впливу, наприклад, зниження рівня злочинності, розширення доступу до житла та інших майнових цінностей, розширення можливостей щодо заощадження, реалізації своїх цілей тощо.

Альтернативні шляхи розв'язання урбанізаційної проблематики шляхом побудови е-держави. Урбанізація поряд зі створенням нових і розширенням існуючих можливостей, що також потребує відповідного публічно-управлінського впливу, чинить суттєвий тиск на різні системи співіснування громадян у межах однієї території. Швидкість, з якою відбуваються урбанізаційні процеси, вимагає від органів публічної влади планування, інновацій, адаптації та гнучкості під час застосування публічноуправлінського інструментарію та творення політики як на загальнодержавному, так і на місцевому рівні. Особливо це стосується країн, що розвиваються. У відповідь на виклики сьогодення та загострення глобальних проблем у процесі формування та реалізації державної політики, міжнародної співпраці формуються нові концепції, економічні моделі, впроваджуються підходи та застосовуються інноваційні інструменти, що відповідають задекларованим міжнародною спільнотою цілям сталого розвитку.

Стрімкий розвиток урбанізму передбачає необхідність обробки все більшої кількості даних про місто та його життя для розробки ефективної політики й оперативного реагування на кризові чи ризикові ситуації. Дані про місто дають ключ до розуміння міського життя, попередження загроз для міста, формування політичного курсу i планів, здійснення оперативного функціонального управління, моделювання можливих сценаріїв майбутнього та вирішення безлічі інших завдань.

Зважаючи на це, у світі панує тенденція до створення «розумних» міст. Свропейська модель побудови «розумних» міст [8] передбачає «взаємопов'язаний розвиток 6 ключових сфер життєдіяльності 
3 широким використанням технологій е-урядування та е-демократіі: розумне урядування, розумна економіка, розумна мобільність, розумні люди, розумне довкілля, розумне життя».

У сучасному розумінні «розумним» називають місто, в якому інфраструктуру мереж, пов'язаних 3 нею масивів даних та інформаційну аналітику використовують для створення:

- розумної економіки - створення нових форм економічного розвитку, таких як економіка мобільних додатків, економіка обміну та економіка відкритих даних;

- розумного уряду - створення «електронного уряду», ухвалення рішень на основі «великих даних», які отримуються та аналізуються кожну секунду, краще та оперативніше надання послуг, підвищення прозорості, можливість громадян брати участь в ухваленні політичних рішень;

- розумної мобільності - створення саморегулюючих транспортних систем і створення ефективних та здатних до взаємодії засобів громадського транспорту;

- розумного середовища - підтримка сталого розвитку в містах, адаптація до зовнішніх ризиків, використання відновлювальних джерел енергії;

- розумних людей - оперативніше інформування населення, підтримка творчих ініціатив, інклюзії, розширення можливостей, забезпечення безпосередньої участі у житті міста.

Побудова розумних міст, що передбачає можливість органів влади на місцевому рівні обробляти масиви даних у реальному часі, має деякі загрози та ризики, що полягають у втручанні у приватне життя. Недоторканість приватного життя вважається основним правом людини, цінністю та гарантованою умовою життя у розвинених країнах. 3 метою уникнення хакерських атак, інших небезпечних впливів на масиви даних та задля забезпечення ефективного функціонування систем розумного міста на державному та/або регіональному рівнях необхідно створювати додаткові системи захисту, щоб дані громадян були максимально захищені, а потреби та інтереси вчасно задоволені.

Висновки та перспективи подальших досліджень. Таким чином, під поняттям «урбанізації» доцільно розуміти процес зміни екологічного, економічного, соціального, гуманітарного та культурного середовищ співіснування людей як у містах, так і у селах, що обумовлені збільшенням кількості міського населення, концентрацією ресурсів та капіталу у містах. Шляхом ідентифікації наслідків урбанізації у розрізі екологічної, економічної, соціальної та гуманітарної сфер встановлено їх взаємообумовленість та каскадний характер, що, в свою чергу, потребує комплексного механізму публічного управління у забезпеченні їх мінімізації чи подолання. Задля обгрунтування напрямів трансформації системи публічного управління та адміністрування використано теорію ієрархічних потреб Абрахама Маслоу (піраміда потреб А.Маслоу) як основу для структуризації урбанізаційних викликів та їх впливу на системи співіснування людей. Це дозволило визначити завдання системи публічного управління та адміністрування в умовах урбанізації. Зважаючи на необхідність акумулювання та обробки значних масивів даних, що можуть стати основою прийняття ефективних публічно-управлінських рішень, охарактеризовано альтернативні шляхи розв'язання урбанізаційної проблематики, зокрема побудова едержави та створення «розумної» інфраструктури.

\section{Список використаної літератури:}

1. Мельник А.Ф. Державне управління : підручник / А.Ф. Мельник, О.Ю. Оболенський, А.Ю. Васіна ; за ред. А.Ф. Мельник. - К. : Знання, 2009. - 582 с.

2. Державне управління: основи теорії, історія і практика : навч. посіб. / В.Д. Бакуменко, П.І. Надолішній, М.М. Іжа, Г.І. Арабаджи ; за заг. ред. П.І. Надолішнього, В.Д. Бакуменка. - Одеса : ОРІДУ НАДУ, 2009. $394 \mathrm{c}$.

3. Ефективність державного управління : монографія / Ю.М. Бажал, О.І. Кілієвич та ін. ; за заг. ред. I.B. Розпутенка. - К. : К.I.C., 2002. - 420 c.

4. Куйбіда В.С. Принципи і методи діяльності органів місцевого самоврядування : монографія / B.C. Куйбіда. - К. : МАУП, 2004. - 432 с.

5. Мамонов I. Потреби та інтереси людини як основа публічного управління / I.Мамонов // Вісник Національної академії державного управління при Президентові України. - 2012. - Вип. 3. - С. 212-220.

6. Long-term global demographic trends: reshaping the geopolitical landscape. - Washington : Central Intelligence Agency, 2001. - $100 \mathrm{p}$.

7. Цілі сталого розвитку 2016-2030 // Представництво ООН в Україні [Електронний ресурс]. - Режим доступу : http://www.un.org.ua/ua/tsili-rozvytku-tysiacholittia/tsili-staloho-rozvytku.

8. European Smart Cities (europeansmartcities 4.0). - 2015 [Електронний ресурс]. - Режим доступу : http://www.smart8cities.eu./?cid=2\&ver=4.

9. Oliinyk O. Public administration of economic and ecological urbanization consequences / O.Oliinyk, L.Serhiienko, I.Legan // Fundamental and applied researches in practice of leading scientific schools. - 2020. - № 1. - C. $27-33$.

10. Сергієнко Л.В. Сутність, особливості та стадії розвитку урбанізації / Л.В. Сергієнко, К.М. Войціщька // Економіка, управління та адміністрування. - 2019. - № 4. - С. 207-213. 


\section{References:}

1. Mel'nyk, A.F., Obolens'kyj, O.Ju. and Vasina, A.Ju. (2009), Derzhavne upravlinnja, pidruchnyk, in Melnik, A.F. (ed.), Znannja, Kyi'v, 582 p.

2. Bakumenko, V.D., Nadolishnij, P.I., Izha, M.M. and Arabadzhy, G.I. (2009), Derzhavne upravlinnja: osnovy teorii', istorija i praktyka, navch. posib., in Nadolishnij, P.I. and Bakumenko, V.D. (ed.), ORIDU NADU, Odesa, 394 p.

3. Bazhal, Ju.M. and Kilijevych, O.I. at al. (2002), Efektyvnist' derzhavnogo upravlinnja, monografija, in Rozputenko, I.V. (ed.), K.I.S., Kyi'v, 420 p.

4. Kujbida, V.S. (2004), Pryncypy i metody dijal'nosti organiv miscevogo samovrjaduvannja, monografija, MAUP, Kyi'v, 432 p.

5. Mamonov, I. (2012), «Potreby ta interesy ljudyny jak osnova publichnogo upravlinnja», Visnyk Nacional'noi' akademii' derzhavnogo upravlinnja pry Prezydentovi Ukrai'ny, Issue 3, pp. 212-220.

6. Central Intelligence Agency (2001), Long-term global demographic trends: reshaping the geopolitical landscape, Washington, $100 \mathrm{p}$

7. Predstavnyctvo OON v Ukrai'ni, Cili stalogo rozvytku 2016-2030, [Online], available at: http://www.un.org.ua/ua/tsili-rozvytku-tysiacholittia/tsili-staloho-rozvytku

8. European Smart Cities (europeansmartcities 4.0) (2015), [Online], available at: http://www.smart8cities.eu./?cid=2\&ver=4

9. Oliinyk, O., Serhiienko, L. and Legan, I. (2020), «Public administration of economic and ecological urbanization consequences», Fundamental and applied researches in practice of leading scientific schools, No. 1, pp. 27-33.

10. Sergiienko, L.V., Vojcic'ka, K.M. (2019), «Sutnist', osoblyvosti ta stadii' rozvytku urbanizacii'», Ekonomika, upravlinnja ta administruvannja, No. 4, pp. 207-213.

Сергієнко Лариса Василівна - кандидат наук з державного управління, доцент кафедри економічної безпеки, публічного управління та адміністрування Державного університету «Житомирська політехніка».

Наукові інтереси:

- механізми державного управління за галузями;

- державна економіко-екологічна політика;

- публічне управління процесами та наслідками урбанізації.

Новосьолов Іван Володимирович - магістрант спеціальності 281 «Публічне управління та адміністрування» Державного університету «Житомирська політехніка».

Наукові інтереси:

- публічне управління в умовах урбанізації;

- публічне управління та адміністрування в забезпеченні розвитку мережевого урбанізму.

Стаття надійшла до редакції 30.04.2020. 